\title{
Rodolphe Gasché
}

State University of New York, Buffalo

\section{Figura czy forma? Punkt widzenia żołądka*}

\begin{abstract}
Abstrakt: Uwagi Immanuela Kanta na temat kwestii kulinarnych, a zwłaszcza jego nierzadko komiczne zalecenia żywieniowe, nie zaprzątały do tej pory uwagi badaczy życia i myśli Kanta, którzy przytaczali je zazwyczaj jedynie w prześmiewczych celach. Co więcej, ponieważ smak kulinarny - właściwość pobudzanego przez pokarm lub napój języka — to smak jedynie zmysłowy i jako taki niedający się komunikować, a w konsekwencji, w przeciwieństwie do sądów o pięknie, niestanowiący części estetyki, wypowiedzi Kanta na temat jedzenia wydają się ledwie poboczne. A jednak w wielu rzucanych jakby na stronie uwagach Kant roztrząsa, dlaczego, mimo że jako właściwość zmysłowa, a więc wadliwa w tym sensie, że nie sposób jej uniwersalnie podzielać, smak stał się w tak wielu językach — zwłaszcza w łacinie i językach romańskich, ale też w niemieckim mianem estetycznej władzy sądzenia: sądu smaku i idealnych odczuć w nich wyrażanych. Niniejszy artykuł wychodzi od tego pytania i omawia wyjaśnienia Kanta, wykazując, że smak podniebienny, tak jak zagadnienia związane z jedzeniem i piciem, odgrywa nieoczekiwanie ważną rolę w rozumowaniu Kanta, w tym w Kantowskim wyobrażeniu myśli jako takiej.
\end{abstract}

Słowa-klucze: smak, Kant, estetyka, sąd smaku, jedzenie

Badacze Immanuela Kanta jak do tej pory po macoszemu traktowali jego przemyślenia dotyczące kwestii kulinarnych, poświęcając im zazwyczaj uwagę o tyle, o ile mogły być one pretekstem do zjadliwych komentarzy dworujących sobie z filozofa. Co prawda wiele jego wynurzeń na ten akurat temat brzmi zabawnie, a nawet przekomicznie, ale przystępując do w miarę szczegółowej analizy kulinarnych rozważań Kanta, zwłaszcza w kontekście jego teorii estetycznych, niewątpliwie powinniśmy pamiętać, że wielu wczesnych biografów Kanta — a zwłaszcza R.B. Jachmann — podkreśla, że Kant nie tylko miał „niezwykle wyrafinowane zmysłowe gusta jako takie", ale także dysponował znaczną wiedzą na temat gotowania. W konsekwencji, jak opisuje Jachmann, „każda pani domu drżała przed jego wnikliwą krytyką i wychodziła ze skóry, aby zadowolić podniebienie owego smakosza" . Poza obiadowaniem za starannie dobranymi stołami

* Artykuł umieszczony w: R. Gasché, Figur oder Form. Die perspective des Magens, [w:] EssenWissen. Erkundungen zur Esskultur, red. H. Lemke, T. Ogawa, München 2008, s. 47-67; przekładu dokonano z wersji angielskiej.

${ }^{1}$ L.E. Borowski, R.B. Jachmann, E.A.C. Wasianski, Immanuel Kant. Sein Leben in Darstellungen vok Zeitgenossen, Berliz 1912 \& 192.

(C) for this edition by CNS 
Królewca, co samo w sobie dawało możliwość obcowania z wyborną kuchnią, Kant, ukończywszy sześćdziesiąt trzy lata, sam zaczął wydawać proszone kolacje. Miał reputację wspaniałego gospodarza pieczołowicie dobierającego gości, zapraszając tych, których towarzystwo gwarantowało interesujące rozmowy przy stole, w których sam zresztą wydatnie i gorliwie uczestniczył. Jachmann pisze: „Tak jak dbał, aby nie zabrakło im rozkoszy podniebienia, tak samo podtrzymywał żywiołowe rozmowy między swymi gośćmi" ${ }^{2}$. Zauważmy jednak również, że chociaż cenił sobie starannie dobrane i kunsztownie przygotowane potrawy, dania, które sam podawał gościom, były skromniejsze niż posiłki, którymi miał okazję się delektować, sam idąc w gości. W rzeczy samej, jak wskazuje jego biograf, Kant zastanawiał się często, w jaki sposób osoba, która „przy swym własnym stole preferowała proste, niewymyślne jedzenie", mogła dorobić się reputacji wybitnego smakosza.

W biografii poświęconej ostatnim latom życia Kanta E.A.C. Wasianski, student, a następnie przyjaciel filozofa, pisze, że pod koniec życia „wielki myśliciel przestał myśleć”, a nawet „coraz częściej wyrażał się w sposób niewłaściwy, to jest figuratywny (sich immer uneigentlicher auszudrücken)"3. Mimo „przebłysków jaśniejącego, choć już nie tak błyskotliwego jak niegdyś, intelektu”, wypowiedzi filozofa coraz częściej zaciemniały, według Wasianskiego, nietrafne figury mowy ${ }^{4}$. Jednakże, jak zauważa ten biograf, mimo ,pewnych ułomności w wyrażaniu się filozofa zachodziło bardzo szczególne podobieństwo między słowami, którymi się posługiwał, a treścią, którą miał na myśli’”. Aby to zilustrować, Wasianski przytacza następującą historyjkę:

[Pewnego popołudnia] w rozmowie przy stole poruszono temat zejścia na ląd Francuzów w Anglii, przy czym padły takie słowa jak ,morze” i ,terra firma”. Kant stwierdził (bynajmniej nie żartując), że na jego talerzu aż nadto jest morza, zaś brak mu stałego lądu. W ten sposób chciał dać do zrozumienia, że w porównaniu z ilością podanych treściwych dań, zaserwowano mu nadmiernie dużo zupy. Innego popołudnia, otrzymawszy na deser pieczone owoce, które podkrojone były na nierówne kawałki, stwierdził, że potrzebuje figury, określonej figury. Miał na myśli, że wolałby, aby owoce pocięto na cząstki o regularnym kształcie ${ }^{5}$.

Wszyscy, którym nieobca jest estetyka Kanta, oczekiwaliby zapewne, że w tych konkretnych okolicznościach domagać się on będzie formy — określonej formy — gdyż zasadniczo pojęcie „figura” nie ma właściwie żadnego ciężaru gatunko-

\footnotetext{
${ }^{2}$ Ibidem, s. 182.

${ }^{3}$ Ibidem, s. 234, 271.

${ }^{4}$ Ibidem, s. 288.

5 Ibidem, s. 295.
} 
wego w Krytyce władzy sądzenia ani w żadnym innym z jego dzieł. Rzeczywiście, w Logice z 1800 roku Kant nazywa pewne sposoby czy też formy wnioskowania figurami, sugerując, że termin ten ma dla niego znaczenie techniczne ${ }^{6}$. W innym tekście odnosi się on do przestrzeni całkowicie określonej swymi granicami. Najczęściej jednak „,figura” dotyczy jedynie formy geometrycznej lub cielesnej i raz za razem pojawia się wraz z pojęciem Gestalt, na przykład w przedkrytycznym eseju Rozważania o uczuciu piękna i wzniostości, w którym Kant pisze, że „niskie krzewy i przycięte [w figury] drzewa w ogrodach są piękne"7. Jednakże w Trzeciej Krytyce to nie figura geometryczna, lecz czysta forma przedmiotu uznana jest za piękną. Krótko: według Kanta uznanie przedmiotu za piękny ze względu na jego formę nie jest pochodną doskonałości tego przedmiotu pod względem geometrycznej regularności. Forma zatem nie jest figurą. Geometrycznej regularności lub też harmonijnego ułożenia części w całość nie można ściśle rzecz biorąc uznać za piękne, gdyż sąd na temat takiej regularności zakłada pewną koncepcję, a zatem nie jest estetycznym sądem smaku, lecz sądem określonym — to jest poznawczym. Czysty sąd smaku dotyczący piękna zachodzi jedynie pod nieobecność określonych pojęć, co oznacza również brak wiedzy o tym przedmiocie. Więc czy Kant wypowiada się niewłaściwie lub też figuratywnie na temat swego posiłku, gdy domaga się figury raczej niż formy? Życząc sobie figury, Kant — jak uważa Wasianski - wyraźnie dawał do zrozumienia, że chce, aby owoce na jego talerzu pokrojono w regularne kawałki o geometrycznych kształtach. A zatem „,figura” to jak najbardziej właściwy termin wybrany stosownie do sytuacji. Bez wątpienia! Ale czy może podstarzały już Kant pragnie też, aby jego danie wyglądało pięknie, i domagając się podania go w cząstkach o regularnych kształtach — figurach wyraża się z gruntu niewłaściwie? Z kolei czy w ogóle można sobie wyobrazić, że Kant pragnął możliwości wydawania estetycznego sądu o swych posiłkach? Czy to możliwe, że życzył sobie, aby potrawy miały formę, a więc były piękne, jak na przykład dzieło sztuki, czy też po prostu chciał, aby podawano mu je w przyjemny, kulturalny sposób, aby wygląd ich miły był dla oka?

\footnotetext{
${ }^{6}$ Kant nazywa figurami trzy rodzaje wnioskowania w mieszanych (w przeciwieństwie do czystych) kategorycznych wnioskach rozumowych, w których położenie przesłanek różni się od ich zwykłego porządku. Różnica taka, a zwłaszcza odwrócenie w takich figurach prawidłowego porządku przesłanek, upodabnia te figury logiczne do figur gramatycznych, jeśli nie do figur retorycznych. Zob. I. Kant, Logika. Podręcznik do wykładów, przeł. A. Banaszkiewicz, Gdańsk 2005, s. 152-155.

${ }^{7}$ I. Kant, Rozważania o uczuciu piękna i wzniosłości, przeł. D. Paskalski, M. Żelazny, [w:] idem, Pisma przedkrytyczne, Toruń 1999, s. 47 (cytat zmieniony). Istniejące (cytowane) polskie thumaczenie tego ustępu nie zawiera frazy „,w figury”. Została tu ona dodana w nawiasie kwadratowym, gdyż występuje ona i u Kanta (,,in Figuren geschnittene Bäume”), i w angielskim przekładzie cytowanym w oryginalnym tekście niniejszego eseju (,trees trimmed in figures”) i jest podstawą argumentacji autora [przyp. thum.].
} 
„W wąskim sensie smak jest to [...]”, jak zauważa Kant, „własność pewnego organu (języka, podniebienia i gardła) polegająca na tym, że jest on specyficznie pobudzany przez pewne substancje rozkładane podczas jedzenia i picia"8. Powiązany z tym jednym, konkretnym organem smak ma dwojaką funkcję: służy albo rozróżnianiu pewnych potraw i określaniu czy też nazywaniu (benennen) ich właściwości - na przykład stwierdzaniu, czy coś jest słodkie, czy gorzkie — albo rozkoszowaniu się i delektowaniu tym, co się smakuje. Podczas gdy rozróżnienia takie jak słodycz czy gorycz pewnych potraw — rozróżnienia będące częścią wiedzy, którą możemy o nich nabyć - mogą liczyć na powszechne uznanie, podobnych roszczeń do powszechnego uznania nie sposób poczynić w wypadku sądu, że pewne smaki są przyjemne lub że przeciwnie — wzbudzają niechęć. Stwierdzenie, że niektóre potrawy są smakowite, inne zaś niestrawne, jest określeniem subiektywnym i jako takie nie może liczyć na powszechną zgodę.

Smak jako smak przyjemny (Wohlgeschmack) ma zatem ograniczoną siłę oddziaływania. Jego roszczenia pozostają wyłącznie prywatne. Ale chociaż smak jako smak rozróżniający (Unterscheidungsgeschmack), to jest władza rozróżniania między właściwościami pożywienia, ma zasięg powszechny, jego poznawcze dokonania wydają się ograniczone do wyróżniania i nazywania jedynie garstki takich właściwości - wśród których słodycz i gorycz to jedna z nielicznych różnic, do których Kant raz po raz się odwołuje. W swym dziele Fizjologia smaku albo Medytacje o gastronomii doskonatej powstałym w roku 1825, czyli nie tak długo po śmierci Kanta, Brillat-Savarin stwierdza, że oprócz tego iż „nieokreślonej liczbie ciągów radykalnych [prostych] smaków", które w dodatku przechodzić mogą nieskończone modyfikacje, potrzeba by zupełnie „nowego języka... aby wyrazić ich wypadkowy efekt, gór arkuszy papieru, aby je zdefiniować i niesłychanych oznaczeń numerycznych, aby przedstawić je wszystkie za pomocą symboli”, nawet jednego, jedynego ,smaku nie udało się [dotychczas] opisać z naukową precyzją". W rezultacie

z konieczności skazani jesteśmy na kilka ogólnych określeń takich jak słodki, cukrowy, kwaskowy, gorzki i im podobne, które w ostatecznej analizie zawierają się w dwóch wyrażeniach — przyjemny lub nieprzyjemny w smaku — wystarczających do wszystkich celów praktycznych związanych z wskazywaniem smakowych właściwości wszelkiej rozpatrywanej substancji o jakimś smaku9 .

${ }^{8}$ I. Kant, Antropologia w ujęciu pragmatycznym, przeł. E. Drzazgowska, P. Sosnowska, Warszawa 2005, s. 173-174.

${ }^{9}$ A. Brillat-Savarin, The Physiology of Taste, or Meditations on Transcendental Gastronomy, przeł. A. Machen, New Haven 1980, s. 25. Istniejący polski przekład Fizjologii smaku Brillat-Savarina (Fizjologia smaku albo Medytacje o gastronomii doskonałej, przeł. J. Guze, Warszawa 2015) jest wyborem z oryginału i nie zawiera cytowanego w tym tekście ustępu. Cytat jest przytoczony w przekładzie tłumaczki niniejszego artykułu na podstawie jego angielskiego brzmienia.

Prace Kulturoznawcze 21, 2017, nr 2

(C) for this edition by CNS 
Brillat-Savarin, który przejawiał znaczne zainteresowanie językiem, co odnotował na przykład Roland Barthes, jasno wskazuje na bliskie powiązanie między językiem jako narządem zmysłu rozróżniającym smaki a językiem jako organem rozróżnień lingwistycznych ${ }^{10}$. Zdolność, lub też niemożność, językowego nazwania różnic smaku, a stąd epistemologicznej ich konceptualizacji, zdaje się też problemem Kanta, jako że wyrażenia używane przez Kanta nie tylko są tak ograniczone jak słownictwo, które stosuje Brillat-Savarin, lecz także sprowadzają się koniec końców jedynie do rozróżnienia, czy coś jest przyjemne, czy też nie.

A zatem nie jest niespodzianką, że — mimochodem właściwie — Kant stawia pytanie, dlaczego smak jako własność jednego zmysłu — ust — chociaż zmysł ten ułomny jest pod względem mocy swych roszczeń, mógł stać się nazwą estetycznej władzy sądzenia, to jest władzy, która wydaje sąd najpierw jedynie o formie rzeczy. Oddajmy głos Kantowi - w Uwadze w Antropologii w ujęciu pragmatycznym zapytuje on:

Jak to się jednak mogło stać, że języki, przede wszystkim nowożytne, estetyczną władzę sądzenia określiły za pomocą wyrażenia (gustus, sapor), które wskazuje jedynie na pewne narzędzie zmysłowe (wnętrze jamy ustnej), a odnosi się zarówno do rozróżniania, jak i wyboru rzeczy, które można kosztować w ten sposób [tzn. za pomocą smaku]? ${ }^{11}$

Przypomnijmy przy tym, że Kant twierdził, iż czysty sąd smaku jako sąd refleksyjny dotyczy jedynie czystej formy obiektu niemającego określonego pojęcia. Rozpoznanie, że rzecz lub jej przedstawienie ma formę, w żaden sposób nie mówi nam niczego konkretnego o samej rzeczy, lecz tylko zapewnia nas, że nieokreślona rzecz zgodna jest z naszymi zdolnościami poznawczymi, a zatem zasadniczo jest poznawalna. Zanim nastąpi jakiekolwiek dalsze dookreślenie nieokreślonego jeszcze przedmiotu, forma tego przedmiotu jest sama w sobie nieokreślona, ale bogata w potencjalne określenia. Czyż owa nieokreśloność czystej formy poddanej ocenie czystego sądu smaku nie sugeruje jakiegoś powiązania ze zmysłem smaku, jako że ubogi zasób językowych określeń różnych smaków podobnie pozostawia je w stanie pewnej niedookreśloności? Nieokreśloność w obu przypadkach sprawia, że sąd zmysłu smaku i czysty sąd smaku to sądy o tym, co się podoba, a co się nie podoba, co przyjemne i nieprzyjemne. Ale pytanie, które stawia Kant - dlaczego smak jako właściwość podniebienia mógł zacząć oznaczać czysty sąd estetyczny — jest tym donioślejsze, że stwierdzenie, iż coś jest lub nie jest przyjemne dla podniebienia, nie wiąże się właściwie z sądzeniem w ścisłym znaczeniu tego słowa. Na początku Krytyki władzy sądzenia Kant wspomina, że w wypadku jedzenia „do tego [...], co w sposób najbardziej żywy jest przyjemne, nie przynależy nawet żaden sąd o właściwości przedmiotu, tak że ci, którzy nastawieni są tylko na delektowanie się [...] chętnie wstrzymują się od wszelkiego

${ }^{10}$ R. Barthes, Czytanie Brillat-Savarina, przeł. E. Wieleżyńska, [w:] idem, Lektury, Warszawa 2001, s. $187-189$.

11 I. Kant, Antropologia w ujęciu pragmatycznym, s. 178. 
wydawania sądów"12. Jak zatem w ogóle możliwe było, że poprzedzające sąd odczucie, takie jak smak, zaczęło oznaczać smak estetyczny, czyli zdolność sądzenia par excellence? Jak wyjaśnić można to niewłaściwe lub też figuratywne użycie terminu „smak” oraz „dziwne” przeniesienie owego terminu na osąd estetyczny? Dokładniej zaś, na podstawie jakiego poszczególnego „sensu” „odczucie jednego z narządów” ust „dało nazwę odczuciu idealnemu, mianowicie [zdolności] zmysłowego i zarazem powszechnie ważnego wyboru w ogóle", innymi słowy sądu estetycznego, który odnosi się wyłącznie do pięknej formy? ${ }^{13}$

Czyste sądy smaku to sądy o pięknej formie. Jako takie są całkowicie odmienne od sądów o tym, co przyjemne i co dobre. W Krytyce władzy sądzenia Kant dowodzi, że sądy odnoszące się do pięknej formy przedmiotu różnią się od sądów o tym, co przyjemne, i o tym, co dobre, przede wszystkim dlatego że te pierwsze obojętnie traktują samo istnienie przedmiotu. Różnica ta często demonstrowana jest za pomocą przykładów kulinarnych. Na przykład ,irokezyjski Sachem [który powiedział], że w Paryżu najbardziej podobają mu się garkuchnie" (KWS, 63; cytat zmieniony) tworzy kontrast wobec kogoś, kto zdolny jest osądzić piękno pałacu, w najmniejszym nawet stopniu nie będąc zainteresowanym posiadaniem czy też zamieszkiwaniem tak wspaniałej budowli. Oparte na zainteresowaniu wywołanym naturalną lub fizyczną skłonnością odczuwanie, że coś jest przyjemne dla zmysłów, nie ma swobody, która właściwa jest przyjemności wywołanej piękną formą jako taką; co więcej, jak już stwierdziliśmy, uznanie, że coś jest przyjemne, nie zakłada w ogóle wolnego wyboru czy sądu. Kant pisze:

[c]o się tyczy tkwiącego w skłonności zainteresowania w tym, co przyjemne, to każdy powiada: głód jest najlepszym kucharzem, a ludziom o zdrowym apetycie smakuje wszystko, co jadalne; toteż takie upodobanie nie świadczy o wyborze dokonanym na podstawie smaku (KWS, 73).

Czysty sąd smaku różni się też od sądu estetycznego dotyczącego dobra, gdyż ten ostatni także wiąże się z interesem. Ale upodobania w dobru nie należy z tego powodu brać za upodobanie w tym, co przyjemne jedynie dla zmysłów.

O potrawie zaostrzającej smak dzięki korzeniom i innym dodatkom mówi się bez wahania, że jest przyjemna, a zarazem przyznaje się, że nie jest ona dobra; wprawdzie bezpośrednio d o g a d z a zmysłom, lecz pośrednio, tj. rozważana przez rozum, który patrzy na następstwa, nie podoba się (KWS, 69; cytat zmieniony).

12 I. Kant, Krytyka władzy sądzenia, przeł. J. Gałecki, Warszawa 2004, s. 67. Przy następnych przywołaniach stosowany jest skrót KWS.

${ }^{13}$ I. Kant, Antropologia w ujęciu pragmatycznym, s. 178-179. 
Bezinteresowność to tylko pierwsze znamię, które odróżnia czysty sąd smaku od tego, co podoba się zaledwie zmysłom (lub od zainteresowania w dobru). Jak twierdzi Kant, „p i ę k n e jest to, co bez pośrednictwa pojęcia powszechnie się podoba" (KWS, 89). Oznacza to, że chociaż sądy na temat czystej formy przedmiotu nie są poznawcze, nie są one $z$ tego powodu bynajmniej wyłącznie prywatnymi sądami takimi jak sądy o tym, co przyjemne, które w rzeczy samej zasadzają się na ,prywatnym odczuciu”. Aby stwierdzić, że w odniesieniu do tego, co przyjemne, sąd ogranicza się zaledwie do konkretnej osoby, Kant ponownie sięga po przykład kulinarny. Zauważa on, że każdy, kto twierdzi, że jakiś przedmiot mu się podoba, mówi o sobie tylko:

[d]latego też, kiedy, mówi: wino kanaryjskie jest przyjemne, a kto inny poprawi to wyrażenie i przypomni mu, że powinien był powiedzieć: jest d la m n i e przyjemne — zgadza się chętnie. I tak ma się rzecz nie tylko z tym, co smakuje językowi, podniebieniu i przełykowi, lecz także z tym, co może być przyjemne oczom i uszom każdego.

Kant podsumowuje: „w zakresie tego, co przyjemne, obowiązuje więc zasada: k a ż d y m a s w ój wła s n y s m a k (zmysłów)" (KWS, 76). Innymi słowy, smak jako właściwość, dzięki której narządy zmysłu rozróżniają to, co przyjemne i nieprzyjemne, a nie obecność piękna od jego braku, ma jedynie prywatny zasięg. „Sądy smaku” jako sądy zmysłu nie mogą mieć uniwersalnych roszczeń, to znaczy w zasadzie nie da się ich powszechnie dzielić ani też komunikować. A zatem w kantowskim sensie nie istnieje estetyka (czy też piękno) odnosząca się do oddziaływania tego, co materialne, na zmysły. Toteż jak się stało, że smak zmysłowy, a zwłaszcza smak podniebienny zaczął oznaczać formę sądu, który dotyczy pięknej formy i który, jak wynika z jego dwóch innych znamion (poza bezinteresownością i powszechnością), wskazuje na celowość bez celu (to jest bez przedstawienia określonego celu) przedmiotu oraz konieczność zadowolenia dostarczanego przez ten przedmiot?

Pierwszą odpowiedź na to pytanie zawiera §33 Krytyki władzy sadzenia, w którym Kant wyjaśnia, że ,jedną z głównych przyczyn, dla których tej władzy wydawania sądów estetycznych nadano właśnie miano smaku" (KWS 196), jest to, że mimo różnic między kosztowaniem potrawy a wyrokowaniem, że przedmiot jest piękny — z których pierwsze „ogranicza się [w kwestii sądu] jedynie do [konkretnej] osoby" (KWS, 76; cytat zmieniony), a drugiemu towarzyszy mniemanie, że wszyscy mogą się z nim w zasadzie zgodzić - oba te akty są subiektywne. Kant pisze, że choćby

ktoś wyliczał mi wszystkie składniki pewnej potrawy i nadmieniał, że każdy z nich jest dla mnie sam przyjemny i jeszcze poza tym słusznie chwalił wartość zdrowotną tego pożywienia - to jestem głuchy na te wszystkie argumenty, próbuję potrawy m y m językiem i m y m podniebieniem i na tej podstawie (a nie podług zasad ogólnych) wydaję swój sąd (KWS, 196).

W sądzie estetycznym na temat pięknej formy, podobnie, polegam na własnych oczach raczej niż na opiniach innych, nawet jeśli opierają się one na obiektywnych kryteriach i ustalonych zasadach dotyczących piękna. Kant twierdzi: 
[Z]atykam sobie uszy, nie chcę słuchać żadnych argumentów i mędrkowań raczej przyjmę, że owe reguły krytyków są błędne, albo że przynajmniej tutaj nie zachodzi wypadek ich zastosowania, niż bym miał dopuścić do tego, by racje dowodowe a priori determinowały mój sąd (KWS, 196).

Tak jak nie pozwolę krytykom wmówić sobie poczucia przyjemności, stojąc twarzą w twarz z pięknym przedmiotem, choćby potrafili „bardziej efektownie mędrkować niż kucharze", tak samo nie dam ucha opiniom kucharzy, mówiących mi, co mam czuć smakując potrawę (KWS, 197). Sama więc subiektywność smaku jako właściwość narządu ust jest prefiguracją autonomii, której domaga się smak jako sąd na temat pięknej formy. I to dlatego mianem „smaku” obdarza się także taki sąd - estetyczny sąd smaku — który nie jest po prostu, jak ujął to Kant, „patologiczny”, ale zawiera też władzę poznawczą.

Oprócz tego pierwszego powodu Kant przywołuje kolejny w Antropologii w ujęciu pragmatycznym. Zanim jednak przejdę to tego kolejnego powodu, dla którego słownictwa smaku używa się również w odniesieniu do sądu estetycznego, muszę pokrótce omówić ten rodzaj przyjemności, który zdaniem Kanta powiązany jest ze zmysłami, a szczególnie ze zmysłem smaku. Jak widzieliśmy, Kant na określenie przyjemności powiązanej ze zmysłami posługuje się określeniem ,przyjemny”. Pisze on:

Przyjemność jest jako bodziec pożądań zawsze jednakowa, niezależnie od tego, skąd by wypływała i jak specyficznie różne byłoby wyobrażenie (zmysłu i czucia obiektywnie wziętych). Dlatego też przy wydawaniu sądu o jej wpływie na umysł idzie tylko o mnogość podniet (jednoczesnych i sukcesywnych) i niejako tylko o masę przyjemnego czucia; tej zaś nie można uczynić zrozumiałą inaczej, jak tylko przez i 1 o ś ć. Przyjemność nie rozwija dlatego kultury i jest sprawą tylko rozkoszowania się (sondern gehört zum blossen Genusse) (KWS, 167).

Rozważany sam w sobie, smak jako właściwość zmysłów ma zaledwie zwierzęcą jakość. Przyjemność, której przysparza, jest niezróżnicowana, stąd też ubóstwo językowo ujmowanych różnic smaku. Co więcej, ponieważ miarą poziomu usatysfakcjonowania smaku podniebiennego jest jedynie ilość, przyjemność ta, jeśli niekontrolowana, nieuniknienie zmierza ku prostackiemu i nadmiernemu spożyciu jadła i napoju, a w formie obżarstwa i pijaństwa obraca się w ogłupiającą rozkosz czy też raczej folgowanie sobie (Genuss), a nawet rozpustę ${ }^{14}$. W Sporze fakultetów Kant relacjonuje, że

${ }^{14}$ W Metafizyce moralności Kant stwierdza, że „[n]nieumiarkowane pochłanianie pokarmów jest przywarą godną zwierzęcia i prowadzi do nadużywania środków spożywczych, przez co zahamowaniu lub zgoła wyczerpaniu ulegają nasze sprawności intelektualne. W rubrykę tę wpisać należy w szczególności o p i l s t w o i ż a r ło c z n o ść. Człowiek znajdujący się w stanie upojenia 
Turcy zgodnie ze swoimi zasadami predestynacji powiadają o umiarkowaniu [...] że na początku świata każdemu człowiekowi wydzielona została porcja określająca, ile w życiu przyjdzie mu zjeść, jeśli zaś przypisaną mu część zje w wielkich porcjach, to krótszy stanie się również czas, w którym będzie j e ś ć, a więc i b y ć ${ }^{15}$.

Podkreślając w Antropologii, że wszelkie zadowolenie — to jest przyjemność zmysłowa - powiązane jest z bólem i zahamowaniem życia, Kant uwyraźnia „ciągłą antagonistyczną grę miedzy nimi ...[i zapytuje] Cóżby innego wynikało bowiem z ciągłego wzmacniania się siły życiowej, która nie wzniesie się przecież powyżej pewnego poziomu, niźli szybka śmierć z rozkoszy?" ${ }^{16}$. Sam w sobie smak jako właściwość zmysłu smaku mógłby, wydaje się, skłonić człowieka, aby całe życie strawił na spożywaniu jednego wielkiego posiłku, osiągając ni mniej, ni więcej jak ,szybką śmierć z rozkoszy”.

A jednak ponieważ człowiek to byt nie tylko zmysłowy, lecz także, w zasadzie, racjonalny, nie tylko może on, ale też ma obowiązek, sprawować kontrolę nad skłonnościami zmysłów. Jego pierwszorzędnym obowiązkiem wobec siebie jako istoty racjonalnej jest inteligentne wykorzystanie pożywienia w celu przedłużenia życia, a nie tylko rozkoszowania się nim. W trzeciej części Sporu fakultetów, poświęconej filozofii i medycynie, Kant, na podstawie samoobserwacji, opracowuje zatem sztukę kontrolowania lub też dietetykę, która bez względu na swe subiektywne pochodzenie ma uniwersalne roszczenia (a zatem jest $\mathrm{w}$ istocie swej podobna sztuce estetycznego sądu) i za cel stawia sobie przedłużenie życia. Ta część Sporu fakultetów zawiera takie zalecenia, jak „utrzymywanie w stanie ciepłoty brzucha, szczególnie gdy pogoda jest chłodna [...] bo w nim właśnie mieszczą się jelita, które długą drogą spowodować mają wydalanie płynnej materii”; lub że ludzie starsi, a zwłaszcza mężczyźni, powinni spożywać więcej

pokrzepiającego jadła i bardziej pobudzających napojów (np. wino), zarówno by spotęgować ruch jelit [...] jak i po to, by do obiegu krwi wprowadzić takie cząstki, które dzięki swej pobudzającej sile zdolne są utrzymać w biegu sieć naczyń krwionośnych ${ }^{17}$.

Z naszego punktu widzenia ważniejszy jest jednak drugi obowiązek: obowiązek inteligentnego wykorzystania - to jest wykorzystania przez wzgląd na ostateczne przeznaczenie człowieka jako bytu racjonalnego — skłonności zmysłowych,

upodabnia się do zwierzęcia i tak też należy go traktować; zaś z powodu wchłonięcia przesadnych ilości strawy popada on w letarg, co na pewien czas całkowicie paraliżuje te spośród jego czynności, które wymagają niejakiej zręczności i bystrego umysłu". Kant idzie nawet o krok dalej, twierdząc, że obżarstwo gorsze jest nawet od uzależnienia od opium, gdyż w przeciwieństwie do niego „angażuje zmysły jedynie w sposób bierny, przez co w uśpieniu pozostaje władza wyobraźni, której bogactwo mogłoby tu odegrać rolę czynną; toteż zniża ono człowieka jeszcze bardziej do poziomu bydła" (idem, Metafizyka moralności, przeł. E. Nowak, Warszawa 2005, s. 301).

15 I. Kant, Spór fakultetów. Wznowione pytanie czy rodzaj ludzki stale zmierza ku temu, co lepsze?, przeł. M. Żelazny, Toruń 2003, s. 156 (cytat zmieniony).

${ }^{16}$ I. Kant, Antropologia w ujęciu pragmatycznym, s. 160-161 (cytat zmieniony).

${ }^{17}$ I. Kant, Spór fakultetów, s. 152, 159. 
szczególnie tych, które odnoszą się do pożywienia i jego środków. Jak zauważa Kant, „[c]złowiek opuszczony na bezludnej wyspie nie upiększałby wyłącznie dla siebie samego ani swej chaty, ani samego siebie; nie szukałby kwiatów, a tym mniej by je sadził po to by się w nie stroić". Człowiek w tym położeniu, odcięty od społeczeństwa, nie podjąłby się wykwintnego gotowania, nie nakrywałby stołu z elegancją ani też nie dbałby o wyrafinowane maniery podczas jedzenia. Kant ciągnie swą myśl następująco:

[T]ylko w społeczności odczuwa on potrzebę nie tylko tego, by być człowiekiem, lecz także na swój sposób ogładzonym człowiekiem (początek cywilizacji). Za takiego bowiem uważa się człowieka, który skłonny i zdolny jest rozkosz swą udzielać innym i którego żaden przedmiot nie zadowala, jeśli upodobania w nim nie może dzielić z innymi (KWS, 215).

Jako istota dopasowana do społeczeństwa i ku niemu się zwracająca, dla której towarzyskość jest warunkiem koniecznym skłonności dla wszystkich naturalnej, człowiek ma obowiązek wykroczenia poza zaledwie osobiste doświadczenia zmysłowe ku uczuciom uniwersalnie podzielanym, takich jak uczucia pobudzane przez piękną formę, oraz udzielania tych odczuć innym. Ze względu na tę społeczną powinność ludzie muszą rozwijać smak w kierunku sądów estetycznych tak, aby osiągnąć poziom powszechności, który umożliwi komunikowanie, co znajdują przyjemnym, a co nie — to jest ,zmysł wspólny” w dodatku do zmysłu osobistego. Jak zauważa Kant, „uważamy za prostacką i nieszlachetną umysłowość tych, którzy nie mają uczucia dla przyrody pięknej [...] i którzy przy jedzeniu czy butelce oddają się delektowaniu samymi tylko czuciami zmysłowymi" (KWS, 224). Ale jeśli, jak widzieliśmy, przyjemności smaku jako właściwości zmysłu smaku są całkowicie osobiste, a zatem niekomunikowalne uniwersalnie, w jaki sposób jedzenie, potrawy i przyjemności z nimi związane mogą w ogóle odznaczać się takim wyrafinowaniem i ogładą, aby sprostać koniecznościom płynącym z obowiązku człowieka wobec siebie samego jako istoty społecznej?

W Uwadze w Antropologii w ujęciu pragmatycznym roztrząsającej, w jaki sposób miano „smaku” odnoszące się wyłącznie do narządu zmysłu ust, przetransponowane zostało na estetyczną zdolność sądzenia, Kant stwierdza, że ,[d]obry posiłek w dobrym towarzystwie jest niezrównany jako ta sytuacja, w której zmysłowość i intelekt jednoczą się w kosztowaniu — co może być przeciągane i często powtarzane z upodobaniem". W momencie, w którym dobry posiłek służy tylko jako ,pretekst utrzymujący towarzystwo razem”, problem, w jaki sposób jedzenie i pożywienie mogą stać się wystarczająco wyrafinowane, aby wypełnić powinności wpisane w człowieczeństwo, zostaje rozwiązany ${ }^{18}$. W dobrym posiłku w doborowym towarzystwie zmysłowość zaspokajają smaki potraw, intelekt zaś zadowala rozmowa. Dokładniej zaś w wybornym posiłku w dobrym towarzystwie przyjemności zmysłów i przyjemności intelektu spajają się w jedną całość.

${ }^{18}$ I. Kant, Antropologia w ujęciu pragmatycznym, s. 178 [cytat zmieniony]. 
Aby posiłek był dobrym posiłkiem, ciągnie Kant, gospodarz nie może polegać na swym własnym zmyśle smaku, „gdyż goście wybraliby być może inne potrawy i napitki, każdy podług swego prywatnego zmysłu". Musi podejmować decyzje, uwzględniając gusta swoich gości tak, „aby każdy mógł znaleźć coś dla siebie”. Krótko mówiąc, ,[a]aranżuje on przeto różnorodność”, co w wyniku daje „ważność względnie powszechną". Taki gospodarz, podsumowuje Kant, łączy sąd estetyczny z sądem rozumowym, a zatem wykazuje się „smakiem estetycznym” ${ }^{19}$. Co więcej, biegłość gospodarza „w doborze takich gości, którzy chętnie włączają się we wzajemne i ogólne rozmowy" - biegłość, którą Kant sam doprowadził do mistrzostwa - chociaż dowodzi bardziej rozumu niż smaku, jest dodatkowym warunkiem dobrego posiłku w dobrym towarzystwie. Jednakże jedzenie w warunkach, w których ,stosunkowo powszechne” sądy o różnorodnych daniach wykraczają poza sądy jedynie zmysłowe, a otoczenie umożliwia żywiołową rozmowę, nie stanowi jeszcze samo w sobie pięknego dzieła sztuki. Takie ostateczne dokonanie estetyczne wymagałoby bowiem prawdziwie powszechnych sądów. Mimo to wyborny obiad w doborowym towarzystwie mógłby być prefiguracją takiego dzieła sztuki.

Chociaż Kant uwielbiał wyrafinowane jedzenie i miał możliwość bankietowania przy świetnych stołach, Królewiec z pewnością nie był kulinarną metropolią, w której można by doświadczać złotego wieku gastronomii — gastronomii, którą we Francji w erze cesarstwa i restauracji zamieniono w swoistą formę sztuki ${ }^{20}$. Kant gotowania nigdy nie nazywa wprost sztuką, nigdy też nie mówi o posiłkach lub ich serwowaniu w kategoriach piękna. W żadnym z jego pism nie występuje wzmianka o pięknej formie jedzenia. Natomiast w wielu miejscach wspomina on „sposób, w jaki udekorowano stół, by sprawiał przyjemność” (KWS, 228), czyli „Zastawę stołową" (KWS, 240; cytat zmieniony) i ,wszelkie powaby, które mogą bawić towarzystwo przy stole” (KWS, 228). Ale, zdaniem Kanta „podobająca się forma" nadana takim rzeczom jest także jedynie „środkiem przekazywania, niejako manierą wykładu" (KWS, 240). Podobająca się forma raczej niż wytworem sztuki pięknej jest wytworem tego, co Kant nazywa „sztuką przyjemną” (KWS, 260). Ale chociaż podobającej się zastawy stołowej, tak jak podanych gustownie potraw, nie można uznać za powszechnie piękną, z pewnością ,zakłada [ona] stan społeczny (komunikowanie się)" oraz dzielenie przyjemnego czucia z innymi, w stanie umysłu, który jest towarzyski, a nie w początkowym stanie, który jest „przeważnie barbarzyński, nietowarzyski i oparty na samej tylko rywalizacji”21. Kulinarna wspólnota, która powstaje, gdy doborowe towarzystwo biesiaduje razem przy wybornych daniach, nie tylko spełnia wymogi wyłaniające się z ludzkiej skłonności do życia społecznego, lecz także obwieszcza, czy też może, do-

19 Ibidem, s. 178.

20 J.-P. Aron, Le mangeur du XIXe siècle, Paris 1973, s. 55.

${ }^{21}$ I. Kant, Antropologia w ujęciu pragmatycznym, s. 175. 
kładniej rzecz ujmując, jest „znakiem” — w sensie „znaku dziejowego”, o którym pisze Kant w Sporze fakultetów - ukazującym dążność rodzaju ludzkiego do ewolucji ku wspólnocie moralnej ${ }^{22}$. Dobry posiłek w dobrym towarzystwie, jak sugeruje Kant, może sprawić, że „,człowiek nabierze ogłady i dobrych manier ( $g e$ sittet), a tym samym przysposobi go do życia w społeczeństwie”. Ale ponieważ „dobre obyczaje, przyzwoitość, maniery, ogłada (wyzbycie się nieokrzesania)” same w sobie nie równają się jeszcze byciu etycznie dobrym, moralnym (sittlich-gut), to, co dobry posiłek w dobrym towarzystwie osiąga, jest ,wyłącznie negatywnym warunkiem smaku". Smak zademonstrowany i dzielony z innymi podczas posiłku jest, według Kanta, „moralnością w jej przejawie zewnętrznym” 23 . Chociaż $\mathrm{w}$ dobrym posiłku w dobrym towarzystwie nie ma niczego pięknego, a więc posiłku takiego nie można nazwać symbolem moralności, negatywny warunek smaku spełniony podczas takiego posiłku, jest drugą przyczyną, dla której „odczucie pochodzące od jednego narządu przez pewien szczególny sens dało nazwę odczuciu idealnemu, a mianowicie [zdolności] zmysłowego i zarazem powszechnie ważnego wyboru w ogóle"24.

Mam nadzieję, że udało mi się pokazać, iż mimo wielu ką́liwych komentarzy Kanta na temat smaku jako własności zmysłu smaku jedynie oraz zwierzęcych skłonności tego zmysłu, smak ma szczególne znaczenie, tak jak kwestie kulinarne w ogóle, dla refleksji Kanta jako takiej. Michel Onfray pokazuje w Le ventre des philosophes. Critique de la raison diétètique, że jedzenie było poniekąd obsesją wielu filozofów, od Diogenesa począwszy na Sartrze skończywszy, a Kant, któremu poświęca cały rozdział swej książki, nie jest bynajmniej wyjątkiem pod tym względem ${ }^{25}$. W rzeczy samej, nawet jeśli w jedzeniu nie kryje się piękno, a smak jest zaledwie sądem zmysłu, który nie mogąc być udzielony innym, pozostaje subiektywny, ważność tego zmysłu, a także tego, co daje rozkosz podniebieniu, może zaiste tyczyć się jego myślenia głębiej niż w przypadku innych filozofów. Wspomnę tu choćby to, że odżywianie się nie ogranicza się przecież tylko do przyjmowania pokarmu, albowiem ,[d]la uczonego myślenie jest pożywieniem, bez którego nie może on żyć, gdy czuwa i jest s a m o t n y; może ono polegać na uczeniu się (czytaniu książek) lub na tworzeniu (rozważaniu i wynajdowaniu)". Dla Kanta myślenie i jedzenie są z pewnością odrębnymi czynnościami. Twierdzi on, że zmuszanie do pracy jednocześnie głowy i żołądka

\footnotetext{
22 I. Kant, Spór fakultetów, s. 135-136.

${ }^{23}$ I. Kant, Antropologia w ujęciu pragmatycznym, s. 181.

24 Ibidem, s. 178-179.

${ }^{25}$ M. Onfray, Le ventre des philosophes. Critique de la raison diétètique, Paris 1989, s. 83-101.
} 
prowadzi do hipochondrii, i zaleca, aby czynnościom tym oddawać się na zmianę, zachęcając nawet $\mathrm{w}$ tym kontekście do zachowania „diety w myśle $\mathrm{ni} \mathrm{u"26.} \mathrm{A} \mathrm{jednak} \mathrm{posługiwanie} \mathrm{się} \mathrm{słownictwem} \mathrm{związanym} \mathrm{z}$ jedzeniem w odniesieniu do myślenia nie jest całkiem nie na miejscu. Z pewnością zaś nie jest to niewłaściwe użycie terminologii. Na przeniesienie miana „pokarmu” w sferę myślenia pozwala (a być może wymusza je nawet) fakt, że jak jedzenie, które służy podtrzymaniu ludzkiego życia, tak myślenie uczonego zachodzi nie tylko, gdy jest on głodny idei, lecz także gdy czuwa on i jest samotny. Myślenie dzieje się w doskonałej pojedynce bez towarzystwa innych w ten sam sposób, gdy jest ono kwestią spożywania jedzenia tylko w celu podtrzymania życia. W końcu zaś nawet najwyższe osiągnięcie rozumu — to jest spojenie wszelkiej wiedzy w systematyczną jedność, którą Kant nazywa architektoniczną — można skonceptualizować w kategoriach analogicznych do fizjologicznego procesu spożywania i trawienia. Pod koniec Krytyki czystego rozumu Kant twierdzi, że całość czy też system jako ,jedność różnorodnych poznań podporządkowanych jakiejś idei”, której wszystkie poznania są ściśle wzajemnie splecione raczej niż rapsodycznie spiętrzone w stertę,

może [...] wzrastać od wewnątrz (per intus susceptionem), ale nie od zewnątrz [...], jak np. ciało zwierzęce, któremu wzrost nie dodaje żadnego członka, lecz bez zmiany proporcji każdy [z członków] czyni silniejszym i bardziej przydatnym do jego celów ${ }^{27}$.

Wzrost per intus susceptionem, dosłownie: który zachodzi wewnątrz zwierzęcego ciała w wyniku spożycia pokarmu, pozwala Kantowi na zastosowanie podobnej terminologii, gdy mówi o tym, co zachodzi w systematycznym budowaniu rozumu, nie zaciemniając przy tym sprawy ani nie schodząc na manowce. Ale to nie wszystko! Ponieważ, jak zauważa Kant, idea będąca „rozumowym pojęciem całości formy" i jako taka dająca jedność różnorakim poznaniom potrzebuje „schematu, tj. określonej a priori na podstawie podstawowej zasady [Princip] celu istotnej rozmaitości oraz uporządkowania części”, aby mogła w ogóle odnosić się do tej rozmaitości, powstaje pytanie, czy ten pośredniczący zarys, czy też monogramma, bez którego żadna nauka nie jest możliwa, nie jest przypadkiem wzorowany na zwierzęcym metabolizmie — spożyciu i trawieniu pożywienia - oraz wewnętrznym wzroście przezeń umożliwianym? ${ }^{28}$ Wskazawszy w Antropologii w ujęciu pragmatycznym, jak dziwne jest to, że smak narządu ust stał się określeniem władzy tak odmiennej jak władza wydawania sądów estetycznych, Kant podsumowuje swą Uwagę na ten temat, stwierdzając, iż

[j]eszcze bardziej osobliwe jest to, że umiejętność (sapor) zmysłowego wypróbowania, czy coś jest przedmiotem, z którego ja sam czerpię rozkosz (a nie czy wybór przedmiotu jest powszech-

${ }^{26}$ I. Kant, Spór fakultetów, s. 160-161.

${ }^{27}$ I. Kant, Krytyka czystego rozumu, przeł. M. Żelazny, [w:] idem, Dzieła zebrane, t. 2, Toruń 2013, s. 710.

${ }^{28}$ Ibidem, s. 710-711. 
nie ważny) została zgoła wyniesiona do miana mądrości (sapientia). Stało się tak przypuszczalnie dlatego, że cel bezwarunkowo konieczny nie wymaga żadnego namysłu i poszukiwania, lecz wchodzi do duszy niejako bezpośrednio, przez smakowanie tego, co jej służy ${ }^{29}$.

Oczywiście Kant odnosi się tu do faktu, że w łacinie, a stąd we wszystkich językach romańskich, sapientia — mądrość — ma swój źródłosłów w sapor, czyli w określeniu zmysłu smaku. Fakt ten jednak można w pełni wytłumaczyć, a dodatkowo jest on kolejnym dowodem na nieodłączność kwestii zmysłowego smaku, który obecny jest w wyższych i szlachetniejszych formacjach rozumowych, a także pozwala nam mówić o nich jako o „smaku” dosłownie. Można założyć, proponuje Kant, że to, co mądrość uznaje za bezwarunkowo ważne cele człowieczego życia, czy to jednostki, czy to całej ludzkości, czyli za dobre same w sobie, jest rozpoznawane przez duszę bez pośrednictwa refleksji. Dusza czy też umysł w takim razie smakują — czyli bezpośrednio kosztują — pewne cele lub prawdy, natychmiast wyczuwając, że są one zgodne z powołaniem człowieka. Tak jak zmysłowi smaku natychmiast podoba się to, co uznaje on za przyjemne, tak dusza natychmiast przyjmuje to, co jej służy. Jeśli subiektywność i towarzyskość to własności wspólne jakże odmiennych władz smaku zmysłowego i smaku estetycznego, bezpośredniość to trzeci powód, dla którego władza, która ocenia bez sądzenia, może oznaczać też władzę sądzenia właśnie. Co więcej, ponieważ to, co bezwarunkowo dobre, wnika w umysł lub duszę przez smakowanie - to jest przez przyswojenie - przyczynia się to również do wewnętrznego wzrostu duszy, tak jak to dzieje się ze zwierzęcym ciałem, które wzrasta od wewnątrz dzięki przyswajaniu pokarmu. W końcu zaś trwała obecność smaku we wszystkich czynnościach człowieka nie tylko uwypukla przedziwny (gdyż pozornie sprzeczny z Kantowską krytyką hedonizmu) prymat zasady przyjemności nad wszystkimi innymi zasadami, lecz także uwyraźnia swoiście uprzywilejowaną rolę ust $\mathrm{w}$ decydowaniu o tym, co jest przyjemne lub rozkoszne, a co nie ${ }^{30}$.

Podsumowując, powrócę na chwilę do anegdoty opowiadającej, jak to Kant domagał się, żeby jego posiłek miał figurę — określoną figurę — raczej niż formę, czyli aby przyjemnie było nań patrzeć. Życzenie to obrazuje smak, gdyż

29 I. Kant, Antropologia w ujęciu pragmatycznym, s. 179.

${ }^{30} \mathrm{~W}$ tym kontekście warto jest przypomnieć, że poza pięcioma tradycyjnie rozróżnianymi zmysłami Brillat-Savarin uwypukla jeszcze szósty zmysł — ,genezyjski, poczucie fizycznego pożądania (le génésique, ou amour physique)". (A. Brillat-Savarin, Physiology of Taste, s. 15). Jak dowodził Roland Barthes, nie było bynajmniej przypadkiem, że autor traktatu o smaku pisze o miłości fizycznej, łącząc ją ze smakiem, a przez to erotyzując niejako zmysł smaku. (R. Barthes, op. cit., s. 197-198). U Kanta natomiast smak wydaje się najbardziej wszechobecnym i dominującym zmysłem. 
przyjemny kształt dania odsuwa na dalszy plan zmysłowy charakter jedzenia oraz zmysłowy proces jego spożywania, zwłaszcza gdy Kant je w towarzystwie swych przyjaciół. Odzmysłowienie pokarmu i spożywania zachodzi przez pokrojenie jedzenia $\mathrm{w}$ regularne lub też geometryczne kształty — to jest $\mathrm{w}$ określone figury - czyli przez uczynienie go rozpoznawalnym lub też poznawalnym za pośrednictwem pojęcia. Smakowe własności jedzenia stają się rozróżnialne o tyle, aby można ich było udzielać innym, jedynie przez ukształtowanie podług określonych figur. Chociaż sąd o przyjemnym wyglądzie jedzenia nie jest czystym sądem sma$\mathrm{ku}$, a sądem określonym, gdyż dotyczy figury, a nie formy, taki sąd jest wszakże $\mathrm{s}$ ą d e m o czymś, co na początku nie pozwala na wydawanie sądów, albowiem jedzenie, a w tym proces jego spożywania, jest tak intymne, czy też prywatne, że jest w zasadzie niekomunikowalne. Jeśli czysty estetyczny sąd smaku — to jest sąd o formie rzeczy jedynie — zachodzi tylko w wypadku rzeczy, dla których nie ma określonych pojęć, czyli w wypadku poznawczo nieokreślonych rzeczy, czyż nie można by powiedzieć, że smak na podstawie przyjemnych figur sygnalizuje sąd o formie? Zważywszy na ostateczną jednostkowość i niekomunikowalność zmysłowego doświadczenia jedzenia, czyż smak nie dokonuje tego, co czysty sąd estetyczny o czystej formie rzeczy pod nieobecność określonych pojęć? Jak starałem się pokazać w tym artykule, abstrahując od jego refleksji o dietetyce, Kant interesował się żywnością nie tylko w sensie sztuki jedzenia, swoistej gastrozofii. Jedzenie i spożywanie go wydają się odgrywać o wiele bardziej zasadniczą, filozoficzną rolę w jego refleksji, jako że zmysł smaku służy w niej nie tylko za trampolinę wyższych zmysłów, lecz także za model, jeśli nie za schemat, całości myśli. Lecz z życzenia Kanta, aby danie miało figurę raczej niż formę wynika coś innego. Jedzenie nie może mieć formy, niemożliwa jest czysta estetyka jedzenia! A jednak życząc sobie, aby danie miało figurę, Kant domaga się, aby nawet coś tak nieokreślonego i niekomunikowalnego jak smakowe własności jedzenia podlegało „stosunkowo powszechnemu” sądowi. W rzeczy samej, stawką w Kantowskich rozmyślaniach nad jedzeniem jest ni mniej, ni więcej tylko ciągle obecne zagrożenie, że natura może nie pozostawać w harmonijnej zgodzie z rozumem.

\section{Przełożyła Patrycja Poniatowska}

\section{Figure, or form? The viewpoint of the stomach}

\section{Abstract}

Immanuel Kant's remarks on culinary matters, above all his frequently hilarious dietetic recommendations, received little attention by Kant scholars, except in order to poke fun at the philosopher. Furthermore, since gustatory taste - the property of the tongue to be affected by food or drink - as merely sensory taste is not universally communicable, and hence does not, like judgments about the 
beautiful, allow for an aesthetics, Kant's elaborations on food seem to be of minor significance. Yet, in several side remarks, Kant raises the question of why taste, although it is the property of a sense clearly lacking in so far as its sensations are not universally shareable, became in so many languages — particularly Latin and Roman languages, but German as well - a name for the aesthetic faculty of judgment, in short, for judgments of taste and the ideal feelings that they express. By following up on this question, and developing Kant's explanations, the paper seeks to demonstrate that gustatory taste, as well as matters of food and drink, play a rather crucial, and unexpected, role in Kant's thinking, including the way in which Kant conceives of thought itself.

Keywords: gustatory taste, Kant, aesthetics, judgement of taste, food

\section{Bibliografia}

Aron J.-P., Le mangeur du XIXe siècle, Paris 1973.

Barthes R., Czytanie Brillat-Savarina, przeł. E. Wieleżyńska, [w:] R. Barthes, Lektury, Warszawa 2001.

Borowski L.E., Jachmann R.B., Wasianski A.C., Immanuel Kant. Sein Leben in Darstellungen von Zeitgenossen, Berlin 1912.

Brillat-Savarin A., Fizjologia smaku albo Medytacje o gastronomii doskonatej, przeł. J. Guze, Warszawa 2015.

Brillat-Savarin A., The Physiology of Taste, or Meditations on Transcendental Gastronomy, przeł. A. Machen, New Haven 1980

Kant I., Antropologia w ujęciu pragmatycznym, przeł. E. Drzazgowska, P. Sosnowska, Warszawa, 2005

Kant I., Logika. Podręcznik do wykładów, przeł. A. Banaszkiewicz, Gdańsk 2005.

Kant I., Krytyka czystego rozumu, przeł. M. Żelazny, [w:] I. Kant, Dzieła zebrane, t. 2, Toruń 2013.

Kant I., Krytyka władzy sądzenia, przeł. J. Gałecki, Warszawa 2004.

Kant I., Metafizyka moralności, przeł. E. Nowak, Warszawa 2005.

Kant I., Rozważania o uczuciu piękna i wzniostości, przeł. D. Paskalski, M. Żelazny, [w:] I. Kant, Pisma przedkrytyczne, Torun 1999.

Kant I., Spór fakultetów. Wznowione pytanie czy rodzaj ludzki stale zmierza ku temu, co lepsze?, przeł. M. Żelazny, Torun 2003.

Onfray M., Le ventre des philosophes. Critique de la raison diétètique, Paris 1989.

Prace Kulturoznawcze 21, 2017, nr 2

(C) for this edition by CNS 